American Journal of Pharmacology and Toxicology 5 (3): 139-144, 2010

ISSN 1557-4962

(C) 2010 Science Publications

\title{
The Effect of Phyllanthus taxodiifolius Beille Extracts and its Triterpenoids Studying on Cellular Energetic Stage of Cancer Cells
}

\author{
${ }^{1}$ Patiwat Sakkrom, ${ }^{1}$ Wilart Pompimon, ${ }^{2}$ Puttinan Meepowpan, \\ ${ }^{3}$ Narong Nuntasaen and ${ }^{4}$ Chatchanok Loetchutinat \\ ${ }^{1}$ Laboratory of Natural Products, Center for Innovation in Chemistry, \\ Department of Chemistry, Faculty of Science, \\ Lampang Rajabhat University, 52100 Lampang, Thailand \\ ${ }^{2}$ Department of Chemistry, Center for Innovation in Chemistry, \\ Faculty of Science, Chiang Mai University, 50300 Chiang Mai, Thailand \\ ${ }^{3}$ Department of National Park, The Forest Herbarium, Wildlife and Plant Conservation, \\ Ministry of Natural Resources and Environment, Bangkok 10900 Thailand \\ ${ }^{4}$ Laboratory of Physical Chemistry, Molecular and Cellular Biology, \\ Center of Excellence for Molecular Imaging, \\ Department of Radiologic Technology, Faculty of Associated Medical Sciences, \\ Chiang Mai University, 50200 Chiang Mai, Thailand
}

\begin{abstract}
Problem statement: The Multidrug Resistance phenomenon (MDR) is the cause of unsuccessful in cancer chemotherapy. The tradition plant is the population used as the alternative medicine in cancer therapy. Due to, $P$. taxodiifolius is medicinal Thai plant which is used as diuretic drug which has never been explored as the anticancer activities. Approach: Air-dried powder of $P$. taxodiifolius leaves and twigs were serially extracted by hexane, ethyl acetate, acetone and methanol. These four extracts were tested the antiproliferative activity on four cancer cell lines. These results lead to successively purify two triternoids that are glochidone (1) and lupeol (2). Both pure compounds were tested the anticancer properties on same cancer cell lines and further investigate the cellular energetic state perturbation by measuring the mitochondrial membrane potential modification. Results: Four crude extracts were extracted and two triterpenoids (glochidone and lupeol) were purified and identified from hexane extract. Our antiproliferative activity of both compounds respectively showed in the $\mathrm{IC}_{50}$ value of K562, K562/Adr, GLC4 and GLC4/Adr equal to 2.2 $\pm 0.6,4.2 \pm 1.5$. 3.1 \pm 1.0 and $3.2 \pm 0.9 \mu \mathrm{g} \mathrm{mL}^{-1}$ for glochidone and $2.3 \pm 0.6,4.5 \pm 1.7,2.3 \pm 0.5$ and $2.6 \pm 0.5 \mu \mathrm{g} \mathrm{mL}^{-1}$ for lupeol. The $\mathrm{R}$ value, which represents the multidrug resistance phenotype, is about 2 for P-glycloprotein overexpression in K562/Adr and 1 for MRP1 overexpression in GLC4/Adr. Conclusion: All crude extractions and two triterpenoids show the clear evidence of anticancer activity of both sensitive and resistance of erythroleukemic and Small cell lung cancer cell lines. Both compounds are not recognized by ABCB1 and $\mathrm{ABCC} 1$ proteins. Our results also indicated that lupeol initiate cell death by mitochondria membrane potential modification specially the sensitive cell line.
\end{abstract}

Key words: Phyllanthus taxodiifolius beille, triterpenoid, anticancer, multidrug resistance, mitochondria membrane potential, cellular energetic state, glochidone, lupeol, antiproliferative activity

\section{INTRODUCTION}

Cancer is one of the major death causes of disease. After the treatment, the Multidrug Resistance phenomenon (MDR) is a major obstacle to successful treatment outcome of many human malignancies cause by the reducing of intracellular drug target accumulation. MDR phenomena often associated with

Corresponding Author:Chatchanok Loetchutinat, Laboratory of Physical Chemistry, Molecular and Cellular Biology, Center of Excellence for Molecular Imaging, Department of Radiologic Technology, Faculty of Associated Medical Sciences, Chiang Mai University, 50200 Chiang Mai, Thailand Tel: +66 53949306 
the over expression of protein transports, cellular energetic state and also cellular oxidative stress. This obstacle was wildly studied on its mechanism to find out the effective anticancer drug. New molecules either from the synthesis or pure compounds of plant extraction were explored (Monkodkaew et al., 2009: Nantapap et al., 2010; Tangjai et al., 2008; Haque et al., 2006). Recently, the tradition plant is the population used as the alternative medicine in cancer therapy.

The Phyllanthus genus belongs to the Euphobiaceae family. By the diversified species of Phyllanthus, these plants have been wildly studied in various activities such as anti-inflammatory, antidiabetic, anti-diarrheal, antinociceptive, hepatoprotective activity and anticancer (Chudapongse et al., 2010; Kumar et al., 2008; Naaz et al., 2007; Shanbhag et al., 2010). The phytochemical study showed that the Phyllanthus genus consist triterpenoids, resins, steroids, alkaloids and phenolic compounds (Khatoon et al., 2006). The research on $P$. urinaria presented the apoptotic cell death in cancer cell lines. Anyway, P. taxodiifolius Beille which is used as diuretics drug in Thai traditional herbal medicine has not been study yet. In this work, we aim to study the anticancer properties by focusing its activity on mitochondrial.

\section{MATERIALS AND METHODS}

Plant extractions: The $P$. taxodiifolius Beille leaves and twigs were collected from Amnatcharoen, Thailand and identified by voucher specimen (BKF no. 127614). It has been deposited at the Forest Herbarium, Department of National Park, Wildlife and Plant Conservation, Ministry of Natural Resources and Environment, Bangkok, Thailand before using. These leaves and twings $(5 \mathrm{~kg})$ were air-dried and grinded to be fine powder before marinate sequentially from hexane $(16 \mathrm{~L} \times 3$ days $\times 6$ times), ethyl acetate $(17 \mathrm{~L} \times 3$ days $\times 6$ times), acetone ( $16 \mathrm{~L} \times 3$ days $\times 7$ times) and methanol (16 $\mathrm{L} \times 3$ days $\times 7$ times) for extraction. All four extractions were evaporated to collect crude extraction and tested the antiproliferation on cancer cell lines. This bioactive information guided us to further purify and identify pure compounds from hexane extraction and then investigate the bioactivity on same cancer cell lines. From the bioassay-guided fractionation, the hexane fraction was separated by chromatographic technique. The hexane extract (40.2 g) was separated by column chromatography over silica gel 300 g. Gradient elution was conducted initially with n-hexane, gradually enriched with ethyl acetate, followed by increasing amount of methanol in ethyl acetate and finally with methanol. Fractions $(500 \mathrm{~mL}$ each) were collected and combined on the basis of TLC behavior. Fraction 2 and 3 which eluted by $10 \%$ ethyl acetate-methanol, was obtained as two white needles which identified as glochidone (1) and lupeol (2), respectively.

Cell and cell culture: The bioactivity of compounds were performed in four cancer cell lines (the erythroleukemia sensitive (K562) and its adriamycin resistance cell line (K562/Adr) and the small cell lung cancer sensitive (GLC4) and its adriamycin resistance cell line (GLC4/Adr)). Cells were cultivated in RPMI1640 medium complement with $10 \%$ fetal bovine serum albumin and $1 \%$ antibiotic at $37^{\circ} \mathrm{C}, 5 \% \mathrm{CO}_{2}$ and 95\% humidity incubator for 3days before experiment. The K562/Adr and GLC4/Adr are characterized as multidrug resistance phenotype by the over expression of plasma membrane proteins that is P-glycoprotein (ABCB1) and MRP1 (ABCC1), respectively.

Cytotoxic assay: The toxicity of compounds on cell growth was tested by incubate each cell line (5000 cells) with various concentration of each compound from 0 up to $250 \mu \mathrm{g} \mathrm{mL} \mathrm{m}^{-1}$ in RPMI-1640 containing $10 \%$ fetal bovine serum albumin and $1 \%$ antibiotic then cultured in $37^{\circ} \mathrm{C}$ for $72 \mathrm{~h}$. Cell viability was determined by using MTT-colorimetric assay. In this assay MTT will be reduced to be formazan crystal (OD560) by the activity of mitochondria. At $72 \mathrm{~h}$ incubation time, $2.5 \mathrm{mg} \mathrm{mL}^{-1}$ of MTT was added in to each sample and incubated at $37^{\circ} \mathrm{C}$ for $4 \mathrm{~h}$. After that the excessive MTT was removed and cells were washed twice with phosphate buffer solution $\mathrm{pH}$ 7.0. Then dimethyl sulfoxide solution was added to dissolve the formazan crystal. The cytotoxic activity (Puapairoj et al., 2005) of compound was presented as the $\mathrm{IC}_{50}$ value, which represent the concentration of compound in which the cellular proliferation was inhibited to $50 \%$. The percentage of cell-growth inhibition (IC\%) was obtained from the following equation:

$$
\mathrm{IC} \%=\frac{\mathrm{C}_{72}-\mathrm{S}_{72}}{\mathrm{C}_{72}-\mathrm{C}_{0}}
$$

When:

$\mathrm{C}_{0}=\mathrm{OD}$ at $560 \mathrm{~nm}$ value represent the initial cell amount of non treated cell (control)

$\mathrm{C}_{72}=\mathrm{OD}$ at $560 \mathrm{~nm}$ value represent the cell amount of control at $72 \mathrm{~h}$

$\mathrm{S}_{72}=\mathrm{OD}$ at $560 \mathrm{~nm}$ value represent the cell amount of treated cell at $72 \mathrm{~h}$ 
The Resistance factor ( $\mathrm{R}$ value) represent the multidrug resistance phenotype of such compound can be calculated as the $\mathrm{IC}_{50}$ value of resistance cell divide by $\mathrm{IC}_{50}$ value of its corresponding sensitive cell line.

Determination of the mitochondria membrane potential $\left(\Delta \Psi_{\mathrm{m}}\right)$ : The mitochondria membrane potential which reflects to cellular energetic state of each cell line was determined by using the kinetic uptake of rhodamine $\mathrm{B}$. The rhodamine $\mathrm{B}$ is a fluorescence probe that can be uptake into cell and accumulated in mitochondria by the defect of it potential. The fluorescence intensity at $582 \mathrm{~nm}$ (excited at $553 \mathrm{~nm}$ ) of rhodamine $\mathrm{B}$ in mitochondria can be determined due to the local quencher by formazan crystals. The initial rate of rhodamine B fluorescence extinction could be determined and calculated to predict the $\Delta \Psi_{\mathrm{m}}$ (mVolt) value of intact cell as descript by Reungpatthanaphong et al. (2003). The effect of 2 pure compounds on mitochondrial membrane potential modification was studies on four cancer cell lines. The $2 \times 10^{6}$ cells of each cell were incubated with pure compound at the $\mathrm{IC}_{50}$ concentration in $2 \mathrm{~mL}$ of Luckhoff $\mathrm{Na}^{+} \mathrm{pH} 7.3$ at $37^{\circ} \mathrm{C}$ for $30 \mathrm{~min}$ before mitochondria membrane potential determination.

\section{RESULTS}

The cytotoxic activity of crude extracts and pure compounds on cancer cell lines: The bioactivity of four crude extracts and two pure compounds were studied on four cancer cell lines. The yield of four crude extracts from fine powder of $P$. taxodiifolius leaves and twigs are 40.2, 37.3, 90.0 and $170.1 \mathrm{~g}$ for hexane, ethyl acetate, acetone and methanol, respectively. The bioactivity study of four crude extracts presented the strong cytotoxic on all cancer cell lines (Table 1).
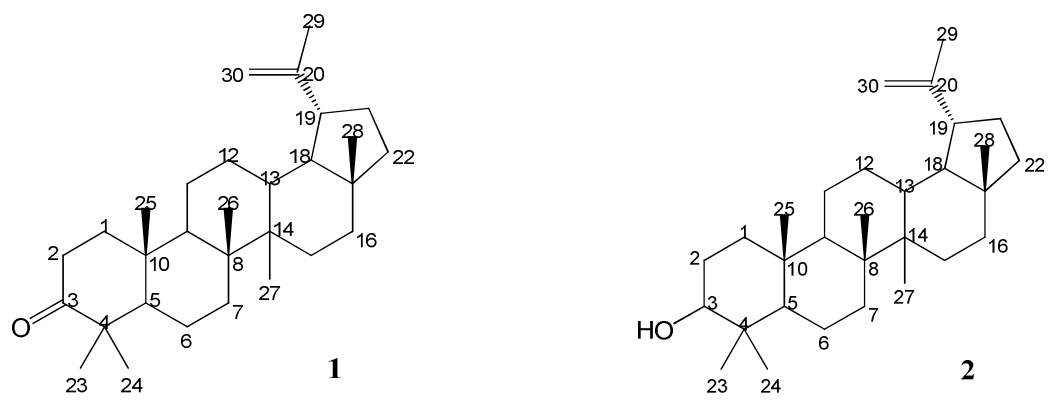

Fig. 1: The chemical structures of glochidone (1) and lupeol (2) and their physico-chemical properties

Note: Compound 1: Lupa-1,20(29)-diene-3-one (Glochidone). Crystals: white needles from $\mathrm{CH}_{2} \mathrm{Cl}_{2}-\mathrm{MeOH}_{\mathrm{m}} \mathrm{m} . \mathrm{p}$. $167.7-168.1^{\circ} \mathrm{C}$ (Lit. $\left.^{22} 164-165^{\circ} \mathrm{C}\right)$. UV $\lambda_{\max }^{\mathrm{EtOH}} \mathrm{nm}(\log \varepsilon): 228(1.50), 330(1.03)$. FTIR $v_{\max }^{\mathrm{KBr}} \mathrm{cm}^{-1}: 2939,2873$, $1670(\mathrm{C}=\mathrm{O}$ stretching of conjugated ketone), 1454, 1380, 1284, 1215, 1099, 1014, 945, 871, 825 EIMS m/z (\% relative intensity): 422[M] ${ }^{+}, 369(6), 300(5), 298(14), 281(20), 269(13), 256(17), 227(10), 208(23)$, 200(24), 178(44), 167(24), 149(100), 125(32), 119(28), 97(34), 81(46), 77(49), 67(74), 55(77). ${ }^{1} \mathrm{H}-\mathrm{NMR}$ $\left(400 \mathrm{MHz}_{\mathrm{CDCl}}\right) \delta(\mathrm{ppm})$ : Table 1. COSY correlations $\mathrm{H} / \mathrm{H}: 1 / 2 ; 2 / 1 ; 13 / 16 ; 18 / 19,21 \mathrm{a} ; 19 / 16 ; 22 \mathrm{a} / 22 \mathrm{~b}$; 29b/30; 30/18 HMBC correlations C-H : 1/9, 25 ; 3/23, 24 ; 4/2 ; 5/1, 9, 23, 24 ; 6/7 ; 7/16a, 26 ; 8/7, 9 ; 9/5, 12b;10/9;11/9, $25 ; 12 / 18 ; 13 / 11 b, 27$; 14/9, 27 ; 15/16a ; 16/28;17/21b, 22b ; 18/16a, 21a, 21 b, 28 ; 19/13, 29a, 29b, 30 ; 20/18, 19, 21b, 30 ; 21/19 ; 22/21b, 18, 28 ; 23/24 ; 24/23 ; 25/1, 2 ; 26/7, 9 ; 27/13 ; 28/16a, 18, 22a, 22b;29/19, $30 ; 30 / 19,29 a, 29 b$

Note: Compound 2: (20 (29)-lupen-3-ol) (Lupeol). Crystals: white needles from $\mathrm{CH}_{2} \mathrm{Cl}_{2}-\mathrm{MeOH}$, m.p. 209.3-210.8 ${ }^{\circ} \mathrm{C}$ (Lit. $\left.{ }^{38} 210-211^{\circ} \mathrm{C}\right)$. UV $\lambda_{\max }^{\mathrm{EtOH}} \mathrm{nm}(\log \varepsilon): 211(1.31)$. FTIR $v_{\max }^{\mathrm{KBr}} \mathrm{cm}^{-1}: 3336(\mathrm{OH}), 2943,2869,1639,1454$, 1380, 1041, 879. EIMS m/z (\% relative intensity): $427\left[\mathrm{M}+\mathrm{H}^{+}{ }^{+}, 369(14), 368(16), 354(26), 338(23)\right.$, 324(13), 306(9), 281(11), 256(12), 229(17), 218(23), 206(26), 204(31), 192(17), 178(48), 161(26), 149(100), 147(19), 121(29), 97(23), 95(29), 79(31), 69(28), 55(41) ${ }^{1} \mathrm{H}-\mathrm{NMR}\left(400 \mathrm{MHz}, \mathrm{CDCl}_{3}\right) \delta$ (ppm): Table 1. COSY correlations H/H : 3/2; 13/18; 18/21a ; 19/18, 22a ; 22a/22b ; 29b/30; 30/18 HMBC correlations C-H : 1/3, 5, 9, $25 ; 2 / 3 ; 3 / 23,24 ; 4 / 3 ; 5 / 6,23,24,25 ; 6 / 5 ; 7 / 26,27 ; 8 / 6,7,9 ; 9 / 25,26 ; 10 / 5,9,25 ; 11 / 9$; 12/18, 27, 30 ; 13/11b, 26, 27 ; 14/18, 26, 27, 28 ;15/9, 16b ; 16/28;17/18, 22b, 28 ; 18/13, 19, $21 \mathrm{a}, 28$; $19 / 29$ a, 29b ; 20/18, 19, 21b, $30 ; 21 / 19 ; 22 / 21 a, 28 ; 23 / 3 ; 24 / 3 ; 25 / 5,11 b ; 26 / 9,11 b, 12 a ; 27 / 13$; 28/16a,18, 22a, 22b;29/19, $30 ; 30 / 19,29 a, 29 b$ 
Am. J. Pharm. \& Toxicol., 5 (3): 139-144, 2010

Table 1: The cytotoxic activity present as the $\% \mathrm{IC}_{50}$ value and resistance factor value ( $\mathrm{R}$ value) of crude extract from hexane, ethyl acetate, acetone and methanol fraction and two pure compounds on K562, K562/Adr, GLC4 and GLC4/Adr cell lines

\begin{tabular}{|c|c|c|c|c|c|c|}
\hline \multirow[b]{2}{*}{ Crude extract } & \multicolumn{6}{|c|}{$\mathrm{IC}_{50}\left(\mu \mathrm{g} \mathrm{mL}^{-1}\right) \mathrm{n}=16$} \\
\hline & K562 & K562/Adr & R-value & GLC4 & GLC4/Adr & $\mathrm{R}$-value \\
\hline Hexane & $28.0 \pm 7.5$ & $70.0 \pm 14$ & 2.5 & $18.6 \pm 4$ & $33.8 \pm 13.7$ & 1.8 \\
\hline Ethyl acetate & $1.2 \pm 0.3$ & $3.90 \pm 3$ & 3.3 & $4.5 \pm 2.3$ & $3.0 \pm 1.5$ & 0.7 \\
\hline Acetone & $1.2 \pm 0.5$ & $7.70 \pm 7.2$ & 6.4 & $4.2 \pm 2.7$ & $2.8 \pm 1.4$ & 0.7 \\
\hline Methanol & $2.4 \pm 1$ & $13.30 \pm 10.2$ & 5.5 & $6.2 \pm 2.8$ & $14.0 \pm 4.7$ & 2.3 \\
\hline \multicolumn{7}{|l|}{ Pure compound } \\
\hline Glochidone (1) & $2.2 \pm 0.6$ & $4.20 \pm 1.5$ & 1.9 & $3.1 \pm 1$ & $3.2 \pm 0.9$ & 1.0 \\
\hline Lupeol (2) & $2.3 \pm 0.6$ & $4.50 \pm 1.7$ & 2.0 & $2.3 \pm 0.5$ & $2.6 \pm 0.5$ & 1.1 \\
\hline
\end{tabular}

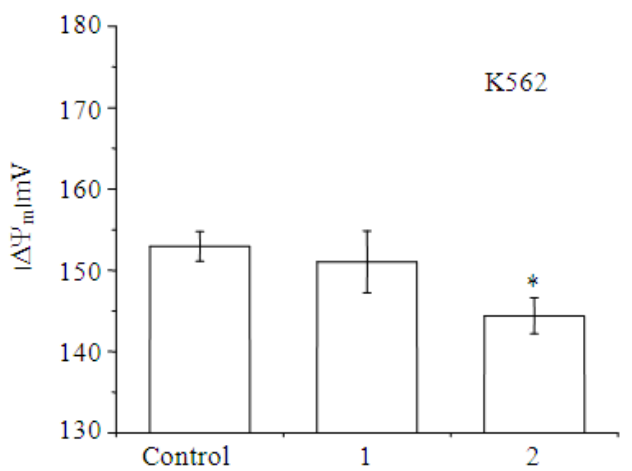

(a)

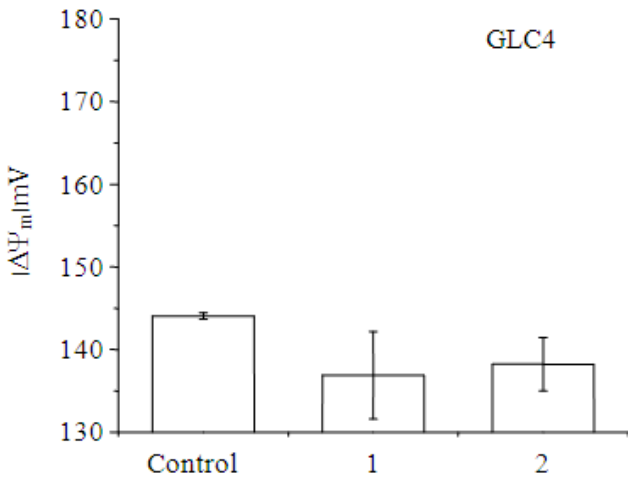

(c)

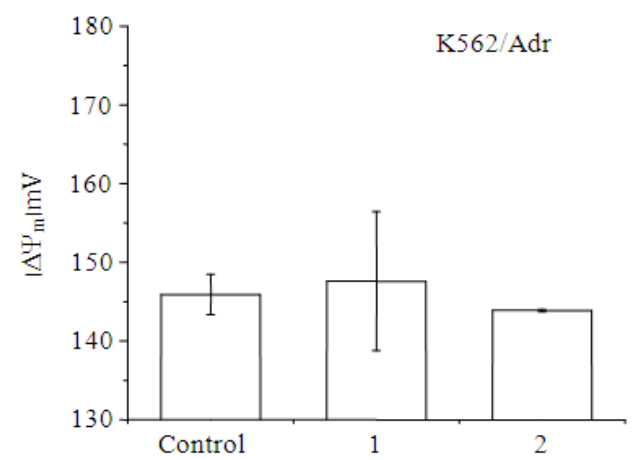

(b)

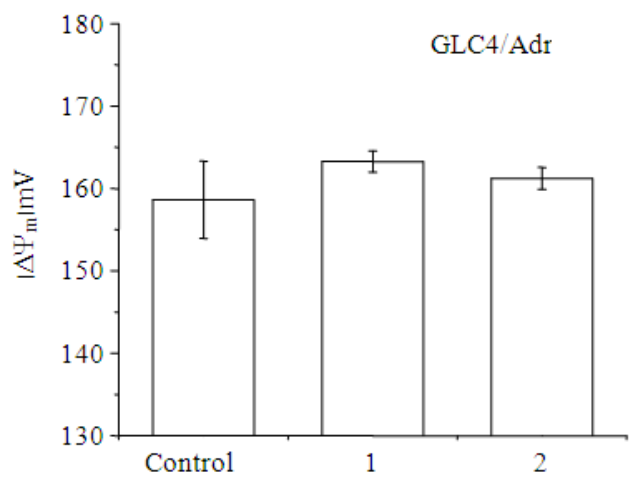

(d)

Fig. 2: The effect of pure compounds extracted from hexane crude fraction (glochidone (1) and lupeol (2)) on the mitochondria membrane potential $\Delta \Psi_{\mathrm{m}}$ of four cancer cell lines; i.e., (a) K562, (b) K562/Adr, (c) GLC4 and (d) GLC4/Adr compare with their untreated cell lines (control)

These results revealed not only toxicity of crude extracts but also the $\mathrm{R}$ value that illustrate the cytotoxic effect of these crude extracts on resistance cancer cell lines compare with its sensitive cell lines. From the calculation, hexane crude extract show the lowest level of $\mathrm{R}$ value on both resistance cell lines that is 2.5 for K562/Adr and 1.8 for GLC4/Adr. According to cytotoxic result, hexane crude extract was further purified and produced two pure compounds. These two compounds (glochidone (1) and lupeol (2)) were identified their chemical structure by spectrometric methods and demonstrated in Fig. 1. These pure compounds were then tested the cytotoxic effect on all same cell lines and they showed the stronger toxic than their crude extract of about 10 times and the $\mathrm{R}$ value close to 1 for GLC4/Adr and about 2 for K562/Adr.

The cellular energetic state modification by pure compounds: The effect of 2 pure compounds (glochidone and lupeol) on the mitochondrial membrane potential $\left(\Delta \Psi_{\mathrm{m}}\right)$ was investigated in four cancer cell lines. The treatment of 2 pure compounds 
result in the $\Delta \Psi_{\mathrm{m}}$ modification. We found that lupeol can reduce the $\Delta \Psi_{\mathrm{m}}$ of both sensitive cell line K562 and GLC4 but not their resistance cell lines K562/Adr and GLC4/Adr while glochidone can slightly reduce $\Delta \Psi_{\mathrm{m}}$ of GLC4 (Fig. 2).

\section{DISCUSSION}

Phyllanthus taxodiifolius is a Thai plant used as diuretics drug in Thai traditional herbal medicine. The cytotoxic on cancer cell line not only show the anticancer activity of all extractions and pure compounds but also the anti multidrug resistance. The certain part of extractions and purification, we obtained triterpenoids compound glochidone and lupeol. Lupeol is a triterpenoids existent in foliage, flowering and fruit trees. Its bioactive was reported as an anti-leukemia and anti-inflammatory (Saleem, 2009). Our result showed that lupeol can disturb the cellular energetic state by the mitochondria membrane potential modification of two sensitive cancer cell lines which involve in the initiation of apoptotic cell death. These results are supported by several studied on triterpenoids also lupeol which are reported as the apoptotic potential by caspase activation and also effect via mitochondria (Chaturvedi et al., 2008; Li et al., 2005; Nigam et al., 2009; Reyes-Zurita et al., 2009).

\section{CONCLUSION}

All crude extractions and two triterpenoids (glochidone and lupeol) purified from hexane fraction of $P$. taxodiifolius leaves and twigs show the clear evidence of anticancer activity of both sensitive and resistance of erythroleukemic and small cell lung cancer cell lines. Our results also indicated that lupeol initiated cell death by mitochondria membrane potential modification.

\section{ACKNOWLEDGEMENT}

The researchers very grateful to Center for Innovation in Chemistry and the Thailand Research Fund and the Commission on Higher Education (Grant No. MRG5080217) and Lampang Rajabhat University for financial support. Moreover, Center of Excellent for Molecular Imaging (CEMI), Department of Radiologic Technology, Faculty of Associated Medical Sciences, Chiang Mai University for convenient use on flow cytometer, COULTER EPICS CL-MCLTM (Coultronics France SA) and Spectrofluorometer (PerkinElmer).

\section{REFERENCES}

Chaturvedi, P.K., K. Bhui and Y. Shukla, 2008. Lupeol: Connotations for chemoprevention. Cancer Lett., 263: 1-13. DOI: 10.1016/j.canlet.2008.01.047

Chudapongse, N., M. Kamkhunthod and K. Poompachee, 2010. Effects of Phyllanthus urinaria extract on HepG2 cell viability and oxidative phosphorylation by isolated rat liver mitochondria. $J$. Ethnopharmacol., 130: 315-319. DOI: 10.1016/j.jep.2010.05.010

Haque, M.E., H.U. Shekhar, A.U. Mohamad, H. Rahman and A.K.M.M. Islam et al., 2006. Triterpenoids from the Stem Bark of Avicennia officinalis. Dhaka Univ. J. Pharm. Sci., 5: 53-57. http://www.banglajol.info/index.php/JPharma/articl e/viewArticle/229

Khatoon, S., V. Rai, A.K.S. Rawat and S. Mehrotra, 2006. Comparative pharmacognostic studies of three Phyllanthus species. J. Ethnopharmacol., 104: 79-86. DOI: 10.1016/j.jep.2005.08.048

Kumar, S., D. Kumar, R.R. Deshmukh, P.D. Lokhande and S.N. More et al., 2008. Antidiabetic potential of Phyllanthus reticulatus in alloxan-induced diabetic mice. Fitoterapia, 79: 21-23. DOI: 10.1016/j.fitote.2007.06.012

Li, C.H., P.Y. Chen, U.M. Chang, L.S. Kan and W.H. Fang et al., 2005. Ganoderic acid X, a lanostanoid triterpene, inhibits topoisomerases and induces apoptosis of cancer cells. Life Sci., 77: 252-265. PMID: 15878354

Monkodkaew, S., C. Loetchutinat, N. Nuntasaen and W. Pompimon, 2009. Identification and antiproliferative activity evaluation of a series of triterpenoids isolated from Flueggea virosa (Roxb. ex Willd.). Am. J. Applied Sci., 6: 1800-1806. DOI: $10.3844 / .2009 .1800 .1806$

Naaz, F., S. Javed and M.Z. Abdin, 2007. Hepatoprotective effect of ethanolic extract of Phyllanthus amarus Schum. et Thonn. on aflatoxin $\mathrm{B}_{1}$-induced liver damage in mice. $\mathrm{J}$. Ethnopharmacol., 113: 503-509. DOI: 10.1016/j.jep.2007.07.017

Nantapap, S., C. Loetchutinat, P. Meepowpan, N. Nuntasaen and W. Pompimon, 2010. Antiproliferative effects of alkaloids isolated from the tuber of Stephania venosa via the induction of cell cycle arrest in mammalian cancer cell lines. Am. J. Applied Sci., 7: 1057-1065. DOI: 10.3844/.2010.1057.1065

Nigam, N., S. Prasad, J. George and Y. Shukla, 2009. Lupeol induces p53 and cyclin-B-mediated G2/M arrest and targets apoptosis through activation of caspase in mouse skin. Biochem. Biophys. Res. Commun., 381: 253-258. PMID: 19232320 
Puapairoj, P., W. Naengchomnong, A. Kijjoa, M.M. Pinto and M. Pedro et al., 2005. Cytotoxic activity of lupane-type triterpenes from Glochidion sphaerogynum and Glochidion eriocarpum two of which induce apoptosis. Planta Med, 71: 208-213. DOI: $10.1055 / \mathrm{s}-2005-837818$

Reungpatthanaphong, P., S. Dechsupa, J. Meesungnoen, C. Loetchutinat and S. Mankhetkorn, 2003. Rhodamine $\mathrm{B}$ as a mitochondrial probe for measurement and monitoring of mitochondrial membrane potential in drug-sensitive and -resistant cells. J. Biochem. Biophys. Methods, 57: 1-16.

Reyes-Zurita, F.J., E.E. Rufino-Palomares, J.A. Lupianez and M. Cascante, 2009. Maslinic acid, a natural triterpene from Olea europaea L., induces apoptosis in HT29 human colon-cancer cells via the mitochondrial apoptotic pathway. Cancer Lett., 273: 44-54. PMID: 18790561
Saleem, M., 2009. Lupeol, a novel anti-inflammatory and anti-cancer dietary triterpene. Cancer Lett., 285: 109-115. DOI: 10.1016/j.canlet.2009.04.033

Shanbhag, T., A. Amuthan, S. Shenoy and Sudhakar, 2010. Effect of Phyllanthus niruri. Linn on burn wound in rats. Asian Pac. J. Trop. Med., 3: 105-108. DOI: 10.1016/S1995-7645(10)60045-4

Tangjai, M., W. Poompimon, C. Loetchutinat, S. Kothan and N. Dechsupa et al., 2008. Spectrofluorometric characterization of behavior and the predominant species of flavonoids in physiological buffer: determination of solubility, lipophilicity and anticancer efficacy. Open Drug Deliv. J., 2: 10-19. 